\title{
Mulheres artesãs da palha: uma análise do perfil empreendedor
}

\author{
Tamires Maria do Nascimento Santos ${ }^{1}$ \\ Waleska James Sousa Felix ${ }^{2}$ \\ Rebeca da Rocha Grangeiro ${ }^{3}$
}

\begin{abstract}
Resumo
O objetivo deste artigo consiste em relacionar as características encontradas em um grupo de artesãs de Juazeiro do Norte com as características empreendedoras reconhecidas pela ciência, com vistas a compreender se estas favorecem ou não a manutenção de seus estabelecimentos. Tais artesãs trabalham com a palha da carnaúba na Rua do Horto em Juazeiro do Norte/CE. Cidade esta que tem suas origens derivadas da ação do Padre Cícero, com sua concepção de desenvolvimento pautada no trabalho e na fé. Para tanto a pesquisa realizada foi de cunho qualitativo com orientação epistemológica baseada na fenomenologia e com pesquisa de campo moldada com base nos preceitos e etapas que regem a metodologia etnográfica. Para a coleta de dados, traçamos uma estratégia de escuta baseada nos princípios da história oral. Admitimos como estratégia de análise a descrição densa. A partir das observações e depoimentos colhidos foi possível perceber que a atividade artesanal realizada por elas se dá, principalmente, pela necessidade de compor a renda familiar. Lembrando que, diferentemente do perfil empreendedor traçado pelos estudiosos no assunto, a estas mulheres, falta, em certa medida, a percepção das oportunidades que permeiam a todo instante suas realidades.
\end{abstract}

Palavras-chave: Empreendedorismo. Características empreendedoras. Artesãs.

\begin{abstract}
The objective of this article is to relate the characteristics found in a group of artisans from Juazeiro do Norte with the entrepreneurial characteristics recognized by science, in order to understand whether these favor or not the maintenance of their establishments. Such artisans work with the carnauba straw at Rua do Horto in Juazeiro do Norte / CE. This city has its origins derived from the action of Priest Cícero, with his conception of development based on work and faith. For this, the research was qualitative with an epistemological orientation based on phenomenology and with field research modeled on ethnographic methodology. To collect data, we draw a listening strategy based on the principles of oral history. And we admit as methodology of analysis the dense description. From the observations and testimonies collected, it was possible to note that the artisanal activity performed by them is mainly due to compose family income. Remembering that, unlike the entrepreneurial profile traced by scholars in the subject, these women lack, to some extent, the perception of the opportunities that permeate their realities at all times.
\end{abstract}

Keywords: Entrepreneurshi., Entrepreneurial Characteristics. Craftswoman.

\section{Introdução}

Muitas são as concepções acerca do empreendedor e seu caráter rico e multifacetado por ser uma pessoa que assume riscos em meio às incertezas, um fornecedor

\footnotetext{
${ }^{1}$ Graduada em Administração. tamiresmarian@gmail.com

${ }^{2}$ Mestre em Administração. Professora da Universidade Federal do Cariri (UFCA).waleskafelix@ufca.edu.br

${ }^{3}$ Doutora em Psicologia Organizacional e do Trabalho. Professora da Universidade Federal do Cariri (UFCA). rebeca.grangeiro@ufca.edu.br
} 
de capital financeiro, líder, decisor, gestor, dono de seu próprio negócio, entre outros. Estas variadas formas de caracterização do empreendedor acabaram gerando uma gama de desdobramentos teóricos e abordagens empíricas acerca do tema (NAIR; PANDEY, 2006). Contudo, apesar das diferenças nos pontos de vistas teóricos, os pesquisadores admitem a ideia base de que o empreendedor, percebido como a pessoa que cria e desenvolve novos negócios, é peça chave para o desenvolvimento econômico de uma sociedade (SHANE; VENKATARAMAN, 2000).

No caso do Brasil, em 2015, a Taxa de Empreendedorismo Total - TTE, chegou a 39,3\%, acima da observada em 2014 (34,4\%). Desde 2002, percebe-se um aumento nas taxas de empreendedorismo. Em treze anos a TTE no Brasil cresceu 18,3\%, saltando de $21 \%$ em 2002 para 39,3\% em 2015. Fazendo uma estimativa, pode-se dizer que, no ano de 2015, cerca de 52 milhões de brasileiros com idade entre 18 e 64 anos estavam envolvidos na criação ou manutenção de algum negócio (GEM, 2015). Nestes dados, encontra-se, pois, a primeira justificativa do interesse pelo assunto - a importância significativa da contribuição das empresas para o crescimento e desenvolvimento socioeconômico nacional.

De acordo com o relatório GEM (2015) dos empreendedores brasileiros em estágio inicial $51 \%$ são do sexo masculino e $49 \%$ do sexo feminino. Isto significa que as mulheres estão participando cada vez mais da economia do país, tal fato está ligado às mudanças na cultura de participação das mulheres no mercado. As famílias estão tomando uma nova forma de organização, onde as mulheres, no decorrer dos anos, passaram assumir o papel de "chefe da família" trazendo para si a responsabilidade pelo sustento da mesma. Dessa forma, as mulheres buscam no empreendedorismo uma saída para melhorar a renda familiar (FIGUEIREDO et al., 2015).

Entretanto, mesmo com a mudança de postura acerca do trabalho feminino que vem sendo difundido ao longo de décadas, algumas mulheres ainda continuam sendo vistas como as principais responsáveis pela administração do lar. Nesse sentido a opção por uma forma de atividade que possa ser realizada no próprio lar, encaixa- se perfeitamente com a necessidade de dar continuidade à reprodução dos papéis sexuais estabelecidos pelo contexto social ainda machista (BARROSO; FROTA, 2010). 
Assim, o artesanato é uma atividade produtiva que se adéqua à necessidade das mulheres em realizar tanto o papel de administradora do lar quanto o de provedora de recursos financeiros. A atividade artesanal surge de um conjunto de conhecimentos formados por diversos povos ao longo de gerações. Sobrevivendo ao processo de industrialização, o artesanato se apresenta como um modelo produtivo não massificado e autorrenovável, sugerindo um processo produtivo que aproveita os recursos naturais e as tecnologias locais (MARQUESAN; FIGUEIREDO, 2014; VERGARA; SILVA, 2007).

Muitas pessoas se utilizam das organizações artesanais como meio de sobrevivência, mesmo em face do processo de massificação da produção (VERGARA; SILVA, 2007). Em algumas localidades, como é o caso de Juazeiro do Norte - CE, campo empírico da pesquisa proposta, apesar do forte processo de industrialização, principalmente no setor calçadista ${ }^{4}$, pode-se perceber que algumas pessoas ainda buscam no artesanato uma alternativa para garantir a sobrevivência (GRANGEIRO; BASTOS, 2016).

No intuito de solucionar os problemas decorrentes principalmente da seca que castigou o Nordeste em meados do século XIX o Padre Cícero difundiu entre os moradores do então povoado de Juazeiro uma cultura de desenvolvimento econômico pautado na díade trabalho e fé. Nesse sentido ao incentivar o trabalho como forma de rezar e a oração enquanto um trabalho e sacrifício destinado a Deus como forma de agradecer os bens materiais, o padre consolidou uma nova cultura política, econômica e social em Juazeiro do Norte (ARAÚJO, 2005).

Com base na ação empreendida pelo Padre Cícero na cidade de Juazeiro do Norte, consolidando-a não apenas como capital da fé, mas, também, como principal polo econômico da região do Cariri, incentivando, entre outras atividades, a cultura do artesanato, que nas palavras de Della Cava (1985) era a atividade econômica mais importante da cidade. Carvalho $(1999$, p. 61) coloca que "essa apologia ao trabalho, em pequena escala e diversificado, contribuiu para atrair para a cidade um grande número de

\footnotetext{
${ }^{4}$ Juazeiro do Norte [...] possui um diversificado parque industrial, que se destaca os ramos calçadistas, sendo este o maior pólo Norte/Nordeste e o terceiro do país, têxtil, folheados, artesanato, bebidas, máquinas, construção civil e metalurgia. Seu comércio é dinâmico e impulsionado pelo turismo religioso (as romarias do Padre Cícero) que trazem para o município um elevado número de pessoas que são absorvidas pelas atividades produtivas do município. Seu PIB em 2010 foi de 53 1.764.685, tendo o setor de serviços e a indústrias com maior participação (CASTRO; OLIVEIRA; PEREIRA, 2016).
} 
artífices e artistas e é responsável pela riqueza da produção artesanal e pela qualidade da arte popular que Juazeiro apresenta".

Diante desta contextualização inicial do campo empírico da pesquisa que ora apresentamos, cabe dizer que a "curiosidade" em perceber se as características empreendedoras tão aceitas pela ciência podem favorecer ou não a manutenção das atividades de um grupo de artesãs da cidade de Juazeiro do Norte - CE emerge, também, da percepção de que esta cidade tem sua origem e desenvolvimento pautado nos ensinamentos do Padre Cícero, que pregava que em cada casa deveria haver uma oficina e um oratório, mantendo forte relação com esta concepção, ainda nos dias atuais.

Por fim, acerca do interesse em estudar o empreendedorismo com foco em mulheres que trabalham com artesanato na cidade de Juazeiro do Norte, cabe ainda dizer que, está atrelado ao fato de este tema estar em ascensão. Este desempenha um papel fundamental no desenvolvimento de uma região que ainda encontra nos pequenos empreendimentos e no artesanato, importante fonte de "sobrevivência". Nesse sentido, o objetivo do presente artigo consiste em relacionar as características encontradas em um grupo de artesãs de Juazeiro do Norte com as características empreendedoras reconhecidas pela ciência, com vistas a compreender se estas favorecem ou não a manutenção de seus estabelecimentos.

Assumimos como pressupostos de pesquisa que as características empreendedoras reconhecidas pela ciência são encontradas nas artesãs de Juazeiro do Norte/CE. E, ainda, que estas características desempenham um papel importante no favorecimento da manutenção de seus estabelecimentos.

Este artigo encontra-se organizado em quatro partes, além desta introdução. Inicialmente foi feita uma reflexão sobre o empreendedorismo com foco na abordagem comportamental, base da análise do perfil dos atores englobados por essa pesquisa. Em um segundo momento são apresentados os aspectos metodológicos que foram utilizados na apreensão dos dados. Posteriormente, os dados colhidos em campo foram confrontados com a fundamentação teórica. Por fim, são tecidas as considerações finais acerca deste trabalho acompanhadas das limitações encontradas, assim como sugestões de futuros estudos. 


\section{Empreendedorismo}

Para Andreoli e Borges (2007) o empreendedorismo é o resultado da rapidez com que as mudanças tecnológicas estão ocorrendo, funcionando com uma mola propulsora da economia. Dessa forma, como observa Dornelas (2008) os empreendedores estão eliminando barreiras comerciais, e culturais, encurtando distâncias, globalizando e renovando os conceitos econômicos, criando novas relações de trabalho e novos empregos, quebrando paradigmas e gerando riqueza para a sociedade.

Embora os estudiosos do empreendedorismo acreditem que há uma confusão acerca da definição do que é empreendedor (FILION, 1997), as definições acerca do empreendedorismo e do empreendedor têm evoluído ao longo dos anos de diferentes maneiras. Para Hisrich e Peters (2004, p. 29), "em quase todas as definições de empreendedorismo, há um consenso de que estamos falando de uma espécie de comportamento que inclui: (1) tomar iniciativa, (2) organizar e reorganizar mecanismos sociais e econômicos a fim de transformar recursos e situações para proveito prático, (3) aceitar o risco ou o fracasso".

\subsection{Abordagem Comportamental e a Teoria dos Traços de Personalidade}

As pesquisas e estudos realizados sobre o comportamento e personalidade do empreendedor baseiam-se na ideia de que o sucesso de um novo empreendimento dependerá principalmente do comportamento de seu ator principal. De acordo com Filion (1999) essa tendência levou os comportamentalistas a buscarem um aprofundamento nos estudos do comportamento empreendedor e a tentarem traçar um perfil de personalidade desses indivíduos. $\mathrm{O}$ intuito desses estudos era identificar traços comuns a esses indivíduos, com a pretensão de se chegar a uma unicidade que pudesse classificá-los em uma categoria peculiar de pessoas. O sucesso do empreendedor é influenciado por diversas variáveis econômicas e sociais, mas ele dificilmente obterá êxito se não apresentar as características mínimas do empreendedor vencedor (OLIVEIRA; SILVA; ARAúJO, 2014). 
Mesmo autores que privilegiam os resultados econômicos do empreendedorismo destacam sua perspectiva comportamental. A exemplo de Schumpeter (1982, p. 89) quando afirma que "os empresários são um tipo especial, e o seu comportamento um problema especial" e reforça em nota que "em primeiro lugar é uma questão de um tipo de conduta e de uma categoria de pessoas [...], de modo que isso constitui sua característica destacada".

Em uma perspectiva sociológica, que busca compreender as influências cultuais e sociais na atividade empreendedora, identificamos Weber (2005). O autor associou o empreendedor com o líder carismático. Indivíduos que são especializados em comunicação, habilidade de articular planos, regras ou uma ampla visão que impressionam a outras pessoas. Weber (2005) descreveu o empreendedor como munido de uma racionalidade instrumental que o faz capaz de entremear sistematicamente alguns objetivos, equipado com o recurso próprio: uma atitude persuasiva (CAMPOS, 2008).

David McClelland foi pioneiro em abordar a importância dos aspectos comportamentais do empreendedor (OLIVEIRA; SILVA; ARAÚJO, 2014). Para o autor um empreendedor é alguém que exerce algum controle sobre os meios de produção e produz mais do que pode consumir, no intuito de venda ou troca, não apenas para o seu consumo pessoal. O autor descreve os empreendedores como indivíduos que conseguem transformar a realidade por possuírem firmeza em suas atitudes. Tais indivíduos, que são poucos, possuem características específicas, que os diferenciam dos demais (MCCLELLAND, 1961 apud BAQUIT, 2008).

Em seus estudos o autor desenvolveu a teoria da motivação psicológica. Para ele, de acordo com sua teoria, as pessoas são motivadas pela necessidade de realização, necessidade de afiliação e necessidade de poder (MCCLELLAND, 1961 apud PAULINO; ROSSI, 2003). Ainda de acordo com o autor, as pessoas com alta necessidade de realização são aquelas que buscam mudar sua realidade, estabelecem metas e se põem em situações competitivas. Seus estudos confirmam que a necessidade de realização é a primeira encontrada nos empreendedores de sucesso e é reconhecida pela psicologia como fator impulsionador para as pessoas iniciarem e construírem um empreendimento.

Concomitantemente às pesquisas realizadas pelos comportamentalistas, no decorrer da década de 1950 foi dado início aos estudos que, baseados na pesquisa dos traços de 
personalidade e de atitudes do empreendedor, tinham o intuito de entender as razões que faziam com que as pessoas empreendessem. Tal linha de pesquisa tem mudado do foco sobre as características pessoais ao foco sobre o processo de criação de um negócio (INÁCIO JÚNIOR, 2002).

Dentre as pesquisas que abordavam o empreendedorismo a partir da teoria dos traços de personalidade, dois trabalhos se destacam por se assemelharem e convergirem para uma mesma compreensão do fenômeno empreendedorismo: Collins e Moore (1970) e Zaleznik e Kets de Vries (1975). Os autores apresentam uma explicação para os aspectos comportamentais relacionados ao empreendedor, partindo da ideia de que a ação empreendedora é uma ação imitada dos modelos copiados da infância (LONGEN, 1997).

Nesse sentido, eles concluíram, a partir de seus estudos, que o empreendedor era impulsionado pelos conflitos originados na infância devido à forma como eram estabelecidas as relações de autoridade com os pais desenvolvendo uma forte ambivalência com a autoridade parental, a qual não era bem aceita, nem rejeitada por eles. Na sua história de vida sempre carregaria uma crise ou uma situação dramática, seja ela dificuldade econômica, situação de perigo, ou outra situação difícil em que o empreendedor teve que se superar e sair acreditando em si mesmo (LONGEN, 1997; PAULINO; ROSSI, 2003).

O estudo de Collins e Moore e Unwalla (1964) baseia-se na teoria da psicanálise. Os principais pontos, sobre as características empreendedoras, descobertos pela pesquisa foram sua alta necessidade de autonomia, independência e autoconfiança. Seguindo mesma linha de estudos, Zaleznik e Kets de Vries (1975) desenvolveram estudos dentro de uma visão psicanalítica. Os mesmos acreditavam que uma infância turbulenta e conflitante influenciaria diretamente na formação de indivíduos empreendedores. Suas vidas eram constantemente marcadas por sofrimentos reais ou imaginários de: pobreza, depravação, morte significativa e solidão (LONGEN, 1997).

Eles acreditam que o empreendedor é sempre motivado por sentimentos persistentes de insatisfação, rejeição e impotência, derivados de conflitos relacionados com os pais. A rejeição do pai e uma mãe dominadora suscitariam uma ação psicológica que exigiria uma compensação para o alívio destes conflitos traumáticos e dolorosos, que poderia levá-lo 
a uma ação autodestrutiva ou alavancá-lo a esforços criativos e inovativos. Este último está relacionado à criação e desenvolvimento de empreendimentos (LONGEN, 1997).

Zaleznik e Kets de Vries (1975) percebem, ainda, o empreendedor como alguém que opera em um teatro empresarial, consequentemente sente a necessidade de aplausos e variadas defesas psicológicas, tais como projeção e ruptura. Entretanto, Kets de Vries (2001, p. 4 apud LONGEN, 1997) acredita que "os empreendedores parecem ser orientados para a realização, gostam de assumir responsabilidades por suas decisões e não gostam de trabalho repetitivo e rotineiro".

Zaleznik e Kets de Vries (1975) postulam que o sucesso do empreendimento é constantemente afetado pela personalidade do empreendedor. Na busca da autorrealização o empreendedor se identifica fortemente com o empreendimento e depende disto para manter sua autoestima e necessidade de controle (LONGEN, 1997).

\section{Delineamento metodológico}

Considerando a natureza simbólica inquirida e em consonância com os objetivos a serem alcançados privilegiou-se neste trabalho a pesquisa de cunho qualitativo, descritivo, com orientação epistemológica encontrada na fenomenologia.

A partir destas orientações epistemológicas e metodológicas, para este trabalho, que se dá segundo a abordagem do estudo de caso, a pesquisa de campo, foi moldada de acordo com os preceitos e etapas que regem a metodologia etnográfica, contando com cinco fontes de evidências: o levantamento de dados (pesquisa bibliográfica e documental), a observação participante, a entrevista não estruturada e de caráter biográfico, as anotações feitas no diário de campo e o registro fotográfico.

Tendo como primeiro recorte a cidade de Juazeiro do Norte, localizada no extremo sul do Estado do Ceará, no chamado Vale do Cariri, distante cerca de 560 km de Fortaleza, o campo de investigação foi constituído por atores sociais, especificamente mulheres, que comercializam, vivem e sobrevivem do comércio do artesanato feito da palha da carnaúba.

Juazeiro do Norte, a maior cidade do interior cearense, possui cerca de 250 mil habitantes (IBGE, 2010), com a maior parte destes concentrados na zona urbana. A 
população é bem heterogênea, formada por pessoas de todos os estados nordestinos, muitos dos quais romeiros, que para esta cidade foram atraídos pela popularidade do Padre Cícero. Juazeiro, retrato da fé, é lugar de muitos Cíceros e Cíceras homenagem ao "Padim" considerado fundador da cidade.

A partir desse cenário, foi estabelecido um segundo recorte espacial do campo. A saber, a Rua do Horto, um dos espaços históricos de reconhecida importância na história dessa cidade e com a história do fundador desta, Padre Cícero Romão.

Como se trata de uma pesquisa qualitativa, a representatividade foi buscada pela diversidade dos perfis dos atores entrevistados. Portanto, para a seleção dos sujeitos, adotei como critérios de inclusão: ser artesã, residente no Horto (Juazeiro do Norte-CE) e desejar participar voluntariamente da pesquisa. A partir destes critérios, contou-se com a participação de oito artesãs entre 29 e 45 anos.

Para a coleta de dados, traçamos uma estratégia de escuta baseada nos princípios da história oral, por nos parecer ser este o caminho mais apropriado ao trabalharmos com histórias de vida dos pequenos empreendedores locais, pois como considera Ferreira (1999) esta é uma opção que tem grande potencial democrático, uma vez que incorpora o testemunho de setores/grupos da sociedade cujas ações são muitas vezes desvalorizadas ou marginalizadas, o que se mostra apropriado considerando o nosso interesse pela história de vida de mulheres artesãs.

A obtenção dos dados ocorreu em duas etapas. A primeira consistiu no levantamento dos dados referentes à investigação através de conversas com outros pesquisadores que já trabalharam o tema. Na segunda fase de coleta de dados, fizemos os primeiros contatos com o grupo, através da observação simples e participante, objetivando uma melhor compreensão da dinâmica de funcionamento do campo estudado. Os dados do contexto sob investigação foram registrados por meio de notas referentes à observação do pesquisador e depoimentos do grupo investigado em um diário de campo.

As observações foram feitas por meio de visitas semanais ao ambiente de trabalho (que também eram domicílio) dos sujeitos participantes da pesquisa. Os encontros semanais em ambiente familiar para as artesãs propiciaram um clima de informalidade durante a pesquisa, o que foi importante para uma melhor apreensão da realidade estudada. Ainda 
para a realização da segunda etapa da pesquisa, utilizamos como instrumento de coleta de dados, a entrevista não estruturada.

Devido ao objeto de estudo admitimos como metodologias de análise a "descrição densa" defendida por Geertz (1989), método de apreensão e apresentação dos dados obtidos, junto aos atores sociais enfocados: mulheres artesãs da Rua do Horto que trabalham fazendo artesanato (chapéus, bolsas, camisas de garrafas) a partir da palha da carnaúba.

Embora se tenha como pilar metodológico a Análise da Descrição Densa, o estudo não foi limitado apenas a esta técnica, uma vez que, os recursos de pesquisa foram além do discurso relacionado diretamente ao ato de empreender, ganhando também, o 'olhar' e o 'testemunho' sobre a interação entre este fazer e a história de vida do ator social, fundamentais para o que se busca compreender.

Sendo assim, procuramos encontrar, a partir das referências dos sujeitos, suas falas e seus silêncios, o explícito e o implícito dos aspectos relativos às características empreendedoras, confrontando-as com as informações obtidas na fundamentação teórica.

\subsection{0 olhar empírico: onde se passa?}

De 'lugar de passagem', um povoado com aproximadamente duzentos habitantes que, até fins do século XIX, não possuía mais do que uma capela, uma escola, trinta e duas casas com tetos de palha, duas ruas e que do ponto de vista comercial, pouco oferecia aos seus habitantes (DELLA CAVA, 1985), Juazeiro chegou a uma das maiores cidades do Ceará, um dos maiores centros de religiosidade popular, centro econômico do Cariri e importante centro de cultura popular do Nordeste (FELIX, 2008).

O crescimento econômico do Juazeiro derivou não apenas das romarias, mas também do fluxo econômico entre a cidade do 'Padim' e as demais cidades do Nordeste. Contudo, Padre Cícero contribuiu para o crescimento da cidade do Juazeiro, e as romarias tornaram-se fonte de migração de indivíduos de vários estados do Nordeste, atraindo diferentes saberes e fazeres. Pode-se dizer, então, que o maior milagre do Padre Cícero foi o milagre econômico (STINGHEN, 2000; ARAÚJO, 2005). 
Padre Cícero estimulou a expansão do artesanato no Joaseiro ${ }^{5}$ a partir de sua concepção de trabalho e fé. O espaço social, no qual atuava o sacerdote, é atrelado, ao mesmo tempo, a um espaço sagrado e a um espaço econômico. Nas palavras de Carvalho (1999):

Essa apologia do trabalho, em pequena escala e diversificado contribuiu para atrair para a cidade um grande número de artífices e artistas e é responsável pela riqueza da produção artesanal e pela qualidade da arte popular que Juazeiro apresenta. Padre Cícero, cada vez mais, renova essa atribuição de fundar, sedimentar e consolidar a cidade que é a Nova Jerusalém das expectativas e dos sonhos do povo romeiro (CARVALHO, 1999, p. 61).

O Juazeiro do Padre Cícero, como é conhecido em todo Brasil, apresenta maior dinamismo econômico e contingente populacional que os registrados pela cidade da qual se emancipou (Crato). É um espaço construído e vivido, em que os elementos norteadores do seu desenvolvimento - trabalho e fé - permanecem gravados e vivos no imaginário coletivo local e são fundamentais para compreender a cultura e suas diferentes formas de representação (ARAÚJO, 2005).

\section{As artesãs e o empreendedorismo: observações e vozes reveladas}

Partindo do pressuposto de que as mulheres da palha do Horto possuem características comportamentais empreendedoras reconhecidas pela ciência e que estas características desempenham um papel importante no favorecimento da manutenção de suas atividades, chego à fase final da pesquisa proposta. Retomando os conceitos que já foram discutidos na fundamentação teórica acerca das características comportamentais que compõem o perfil empreendedor, busquei, através das vozes reveladas nas conversas tidas com as mesmas e das observações registradas em diário de campo, relacionar o que ouvimos e observamos com o conhecimento produzido em meio científico, a fim de confirmar ou não o pressuposto dessa pesquisa.

O empreendedorismo é o envolvimento de pessoas e processos que, juntos, transformam ideias em oportunidade criando algo com valor dedicando o tempo e esforços

\footnotetext{
${ }^{5}$ A grafia do lugar era Joaseiro até 1914 e, a partir de então passou a ser denominado Juazeiro do Norte. 
necessários, assumindo riscos psíquicos, financeiros e sociais intrínsecos correspondentes e recebendo as recompensas da satisfação e independência econômica e pessoal (HISRICH; PETERS, 2004; DORNELAS, 2008).

O termo "empreendedor", por sua vez, possui várias definições, porém, uma das mais antigas e que provavelmente melhor represente o espírito empreendedor seja a de Schumpeter (1982), para quem o empreendedor é aquele que extingue a ordem econômica existente através da inserção de novos produtos e serviços, a partir da criação de novas formas de organização ou pela exploração de novos recursos e materiais.

Os estudos comportamentais sustentam-se na noção de que o sucesso de um empreendimento dependerá principalmente do comportamento de seu ator principal, conforme já discutimos na fundamentação teórica. De acordo com Filion (1999) essa tendência fez com que os comportamentalistas buscassem um aprofundamento nos estudos do comportamento empreendedor e a tentarem traçar um perfil de personalidade dessas pessoas.

De acordo com os estudos realizados por McClelland, apresentados na década de 1960, os empreendedores possuem uma alta necessidade de realização social, além de gostarem de correr riscos, fato que os levam a desprender maiores esforços (GREATTI, SENHORINI, 2000).

Entretanto, embora uma das artesãs afirme estar satisfeita com a profissão, nos discursos das artesãs em relação à realização pessoal na prática do artesanato percebemos que se elas pudessem mudar sua realidade, elas mudariam sua profissão, conforme transcrito abaixo.

Hoje eu me sinto bem e realizada no que eu faço. Mas se eu pudesse escolher, se hoje eu tivesse dez anos, eu investiria no meu estudo pra ter uma nova profissão (M. L. N. V. 40 anos, artesã).

Vixe Maria, o que é que eu mudaria. Mulher eu nem sei. Quem sabe arrumar um emprego melhor pra não tá dependendo desse, mas só esse a gente vai batalhando nesse mesmo (J. O. S. 29 anos, artesã).

Não (se referindo à questão de ser realizada). Eu não vou dizer a você que me sinto, porque não. [...]. Eu não ganho dinheiro suficiente para pagar minhas contas no final do mês. Mas pode ser que em outra entrevista eu diga: não agora eu estou. (C. A. T. 45 anos, artesã). 
A explicação psicológica para o empreendedorismo baseia-se na ideia de que existe um conjunto de pessoas detentoras de características próprias e/ou personalidades especificas que poderiam ser associadas ao sucesso dos empreendimentos.

Uma das características atribuídas ao empreendedor está associada à capacidade de liderar:

No grupo que estava lá pude perceber que tem umas artesãs mais ativas que outras. No primeiro momento consegui identificar uma característica de liderança na artesã M. L. N. V., que me pareceu ser uma das artesãs de referência do grupo (o grupo demonstra uma certa dependência das opiniões dela), parece dominar a técnica do trançado da palha, se mostrou disposta a ensinar, além apresentar traços de criatividade. (Trecho do diário de campo).

Mais uma vez contradizendo o que afirmam os comportamentalistas sobre a motivação psicológica de um empreendedor, onde de acordo com McClelland (1961 apud PAULINO; ROSSI, 2003), as pessoas são motivadas pela necessidade de realização, necessidade de afiliação e necessidade de poder, bem como, as pessoas com alta necessidade de realização são aquelas que buscam mudar sua realidade, estabelecem metas e se põem em situações competitivas, uma das artesãs refletindo sobre a importância de mudar a realidade em que vive afirma que:

Sim, às vezes a gente pára pra pensar assim, a gente pensa é quem sabe um dia chega encomenda de fora, a gente fazer peças diferentes, e ai... (J. O. S. 29 anos, artesã).

No tocante ao estabelecimento de metas, a mesma artesã expõe a dificuldade que possui de trabalhar com planejamento.

\footnotetext{
Mulher assim, às vezes a gente num tá nem muito ligada, mas tem vez que devido ao homem tá ligando direto pedindo ai a gente avexa, [...]. O homem queria que viajasse 5 saco de camisas de garrafa ai mulher foi e veio, conversou com a gente. Assim sobre pressão a gente trabalha com vontade, mas sem ser a gente trabalha assim, mas não se dedica tanto. (J. O. S. 29 anos, artesã).
}

Assumindo que as características pessoais dos empreendedores desempenham um papel importante para a manutenção de suas atividades pude observar: 
A displicência por parte de algumas das artesãs que compõem o grupo participante do projeto ${ }^{6}$ é notória. Enquanto as universitárias e professoras que fazem parte do grupo de extensão responsável pelo projeto tentam colocar suas ideias para as artesãs algumas delas ficam de conversas paralelas, outras nem sequer se dão o trabalho de se sentar junto com o restante no mesmo cômodo da casa do Horto onde ocorrem os encontros. Elas, também, não conseguem se reconhecer como grupo, fato que eu acredito ser um entrave ao desenvolvimento das atividades propostas (Trecho do diário de campo).

Ao mesmo tempo em que os comportamentalistas desenvolviam suas pesquisas, outro grupo de pesquisadores iniciavam seus estudos baseando-se nas nos traços de personalidade e de atitudes dos empreendedores. O objetivo desse estudo, já discutido anteriormente, era entender as razões que faziam com que as pessoas empreendessem.

Nesse sentido, eles concluíram que o empreendedor era incentivado pelos conflitos originados na infância. Na sua história de vida sempre haveria uma crise ou uma situação dramática, seja ela dificuldade econômica, situação de perigo, ou outra situação difícil em que o empreendedor se viu obrigado a superar e sair acreditando em si mesmo (LONGEN, 1997; PAULINO; ROSSI, 2003).

Em termos práticos, os conflitos e crises gerados na infância justificariam a dificuldade que algumas pessoas encontram ao trabalhar em organizações burocráticas, a menos que sejam diretores das mesmas. Corroborando da mesma ideia Collins e Moore de 1964 (apud LONGEN, 1997) tratam da necessidade de autonomia, independência e autoconfiança como características empreendedoras. Seguindo mesma linha de estudos, Zaleznik e Kets de Vries (1975) acreditavam que uma infância turbulenta e conflitante influenciaria diretamente na formação de indivíduos empreendedores (LONGEN, 1997). Nas histórias de vida das três artesãs entrevistadas encontramos sinais das dificuldades vividas por elas e confirmadas nos discursos das mesmas.

Eu vim de uma família da parte de meu pai que gostava de muita bagunça e eu tinha muito medo aí meu pai era muito danado. Mataram ele cedo demais e minha mãe se ajuntou novamente e eu não me dava bem com meu padrasto. Aí eu fui e me ajuntei logo cedo (12 anos), mas num tô arrependida não, até hoje (C. A. T. 45 anos, artesã).

(Continua)

\footnotetext{
${ }^{6}$ A grafia do lugar era Joaseiro até 1914 e, a partir de então passou a ser denominado Juazeiro do Norte.
} 
Na verdade, a minha infância foi trabalhando, porque eu fiquei sem pai com um ano e seis meses. [...]. Mas minha infância na verdade era, começava o ano estudando quando no mês de maio, mês de junho, minha mãe ia ajudar minha madrinha a fazer a coleta de legumes eu já ia com ela, já parava os estudos, quando eu ia começar a estudar novamente já era setembro/outubro aí pronto. Posso dizer que nem tive tempo de estudar e nem condições. As dificuldades quando eu comecei, eu não sei nem lhe falar. Hoje eu sei, antes não. Agora as vantagens que eu sei, porque eu tinha que trabalhar para ajudar em casa. Até mesmo na comida, porque hoje quando morre um homem, o dono da casa, se for agricultor já fica uma pensão né, antes não, quando ela veio conseguir uma pensão devido a morte do meu pai já tinha dez anos que ela era viúva. Quer dizer, na época que eu comecei a trabalhar, eu não comecei porque eu gostava na verdade, eu comecei por necessidade (M. L. N. V. 40 anos, artesã).

Não lembro assim bem exatamente né, mas eu lembro algumas coisas. Era uma vida muito difícil, porque tudo era mais difícil naquela época, num tinha esse negócio de tá comendo bem, era o que tinha mesmo, mas dava pra ir levando, mas hoje em dia graças a Deus a gente 'veve' rico a vista de lá (J. O. S. 29 anos, artesã).

Entretanto, apesar de encontrarmos traços de dificuldade nas histórias de vida das artesãs, conforme já explicitado acima, todas elas colocam que se pudessem escolher não teriam a profissão que exercem hoje.

Outro ponto importante colocado por Rossoni e Teixeira (2006), é a questão dos benefícios de seus relacionamentos. A importância do bom relacionamento também é percebida por elas.

Mulher quem ajudou muito nós mesmo foi dona L. A. B., ela foi uma madrinha e tanto para gente, porque essas garrafas surgiram através dela, a gente já trabalha com ela já faz muitos anos [...] (C. A. T. 45 anos, artesã).

Com certeza. Eu acho que sim, como no caso essa artesã já me indicou pra essa lojista e se eu fosse tão fechada, eu não conversasse com as pessoas, também às vezes você se recusa a falar com as pessoas sobre algo da sua vida, então, como eu conversei com essa pessoa, eu expliquei pra ela, mas não tinha a quem vender. Essa pessoa já me indicou outra pessoa, então eu penso assim, que o conhecimento é fundamental, porque através de um cliente ou um amigo você consegue 10 clientes, então eu acho que sim que o conhecimento e a comunicação são fundamentais (M. L. N. V. 40 anos, artesã).

Não muito não, assim, algumas peças que a pessoa vai fazer que não sabe bem, ai tem que pedir explicação a um e a outro, mas muito não, eu acho que a partir do momento que você aprende, aquela carreira principal o resto é só dica, pega no ar. Não, o povo ensina bem graças a Deus, nós num tem isso não. Todo mundo que diz me ensina isso, venha aqui que tal hora eu lhe ensino (J. O. S. 29 anos, artesã).

Bom na realidade parceiro existe quando você participa de uma associação, vê participando de uma associação você tem parceiro, tem o SEBRAE, tem o Ceart, tem a federação, que todos eles de alguma maneira, se não é financeiramente, com conhecimento, com palavras, com orientação, através de um curso, ajuda muito. Agora se você for ser artesã, individualmente, sem ter uma associação o seu parceiro é você (M. L. N. V. 40 anos, artesã). 
Durante a pesquisa bibliográfica realizada para a construção da fundamentação sobre o empreendedorismo, e corroborando com Filion (1997), percebemos que falta de consenso sobre o perfil empreendedor, visto que cada autor busca definir esse indivíduo baseando-se nas premissas de suas próprias disciplinas. Porém, conseguimos perceber algumas semelhanças na percepção das características empreendedoras, dentro de suas disciplinas.

Com base nisso a maioria dos autores que tratam do comportamento empreendedor concordam que são pessoas que assumem riscos planejados; característica encontrada apenas em uma das artesãs conforme podemos ver nas suas próprias palavras:

\begin{abstract}
É eu acho que melhorou sim, pra falar a verdade mesmo, o artesanato pra mim, melhorou muito depois das camisas de garrafa, [...]. Então essas camisas é um tipo de artesanato que você não tem despesa, quanto mais você fizer você ganha. Então se você tem uma visão de você, chegou um pedido, se você pensar eu vou tentar fazer cinco mil peças, você não faz só, mas ai você sai buscando pessoas que não querem enfrentar a batalha completa, [...], então essas pessoas que não querem fazer do inicio ao fim, então a gente sai, então faça, você faz isso, outro faz aquilo, quando você pensa que não você fez 5 mil 8 mil camisas, [...]. Você tem que ter uma visão que pra você ter um bom êxito, um bom retorno financeiramente, quanto mais você fizer, melhor, então quanto mais ajuda você tiver nas suas peças, você vai ter um retorno melhor tanto pra quem faz mais você como pra você próprio, então eu acho que melhorou muito depois das camisas. (M. L. N. V. 40 anos, artesã).
\end{abstract}

Os empreendedores também são pessoas que conseguem enxergar e aproveitar oportunidades de negócio, mais uma vez, como se pode perceber na fala das artesãs, apenas uma delas demonstra possuir esse tino para detectar oportunidades.

\footnotetext{
E hoje a dois anos, de dois anos pra cá melhorou com uma pessoa que eu conheci, assim porque, antes eu trabalhava nas camisas ou em alguma encomenda, mas assim quando dizia assim, Janeiro até junho se tivesse camisa de garrafa fazia se não tivesse eu estaria parada, só trabalhava se tivesse uma encomenda, mas ai, através de outra artesã, eu conheci uma moça na rua que tem uma loja e ela compra diretamente de primavera a verão, então [...] pra mim, o artesanato tem dado mais lucro através desse atravessador. Aí tem gente que diz: ah eu vendo um chapéu a ela por 20 centavos, ela vende por 30/40 centavos tá ganhando outro tanto, mas ai eu não vejo assim, eu vejo que se eu faço uma miniatura que dá, que eu sei que dá pra vender por 20 centavos, eu não quero saber por quanto ela vai vender, eu quero saber se eu não to tendo prejuízo [...]. Pra mim de dois anos pra cá o artesanato tem melhorado (M. L. N. V. 40 anos, artesã).
}

Ao contrário do discurso acima, os depoimentos de duas artesãs registrados em momentos finais de coleta de dados indicam a necessidade que elas possuem de esperar que terceiros mostrem o que deve ser feito. 
É véspera de dia de finados e a romaria que ocorre nesse período é uma das maiores do ano, me chama atenção os bens simbólicos expostos nas calçadas das casas da Rua do Horto, são imagens do 'Santo da casa', chapéus (não só de palha, mas também de outros materiais), fitinhas do Padre Cícero entre outros. Porém, para minha surpresa, os chapéus expostos a venda nas calçadas da Rua do Horto, que agrega várias artesãs da palha, não são fabricados por elas, mas vêm de Sobral. Eu fiquei me perguntando como elas não enxergam a oportunidade de mostrar seus produtos (trecho do diário de campo). Ai a gente trabalha, faz chapéu, faz chapeuzinho, faz o que a mulher quiser na rua, o que encomendarem (J. O. S. 29 anos, artesã).

Assim, eu faço agora as peças do projeto que a gente vai começar a fazer e também os chapeuzinhos, que a gente trabalha para o centro de cultura fazendo. [...], mas vezes acontece da gente fazer bolsas, as vezes é algum pedido ai a gente faz, chapéu mesmo grande, alguns variam, depende se alguém fizer alguma encomenda. Ai a gente faz (C. A. T. 45 anos, artesã).

\section{Outro fator característico de um empreendedor é a capacidade de ter iniciativa.}

\section{Apenas uma delas demonstra possuir essa característica:}

Eu comecei assim, porque, quando a gente chegou aqui sempre as mulheres tem um costume de se sentar nas calçadas e ficar trabalhando, ai eu via aquilo e me dava vontade, né, ai eu tentei, sentava lá e ficava interessada ai, fui aprendendo uma coisa, aprendendo outra e pronto, assim eu aprendi (J. O. S. 29 anos, artesã).

Em outra fala, entretanto, vemos que a responsabilidade pelo sucesso ou fracasso é colocada nas mãos de terceiros.

Acho, porque se a gente não insistir, a gente não vai para frente, a gente não vai vencer, o grupo de artesãs não vai para frente. Nos já tivemos muita oportunidade, assim, já veio curso do SEBRAE, do Ceart, [...] a gente pode dizer assim, esse projeto veio, veio, e veio em boa hora. Numa hora que nós estamos precisando muito. Nós podemos dizer: nós estávamos lá no fundo do poço, nós estamos tentando sair, porque certo, nós fazia as garrafas, o trabalho principal mesmo era as garrafas, outro trabalho não tinha. Tinha assim, as bolsas, eu mesma nunca fiz pra vender no mercado central. Porque no centro de cultura mesmo, se você fizer aquelas bolsas que você viu lá na casa, se você colocar no centro de cultura, ela mofa lá. Mofa mesmo. É o que disse a Jeanine: nós temos que ter divulgação é lá fora, [...], nunca tivemos a oportunidade de dizer assim, não hoje vai ter uma feira em tal canto, nunca ninguém se interessou em dizer: mulheres da palha façam bolsas tal para eu levar, o Ceart em Fortaleza, [...], eu fiz um curso de relações humanas uma vez, e o professor achou ruim porque eu disse que eu não ganhava dinheiro do meu trabalho, [...] Eu digo olhe professor a gente faz as coisas, ai ele e as bolsas que vocês fazem, eu digo olhe professor, vamos lá no centro de cultura o senhor visita e ver as bolsas lá mofada [...]. Ai ele disse a mim que é porque a presidente na época, ela não se interessava em mandar peça para o Ceart, SEBRAE.

(Continua) 
Eu digo ai já é um problema da associação, que eles quem tem lá que resolver. Né? [...], a gente tem que correr atrás, mas na época ela não corria. Pronto nós ficamos paradas esse tempo todinho, agora com o projeto ${ }^{7}$ está desenvolvendo a gente (C. A. T. 45 anos, artesã).

Em relação à determinação, comprometimento e a persistência, traços em comum encontrados nas pesquisas comportamentais, segundo as próprias artesãs:

Com certeza, a gente tem que ter atitude né, (J. O. S. 29 anos, artesã).

Hoje eu gosto, mas assim, eu gosto e tenho prazer no que eu faço, [...] o artesanato, ele é um trabalho que ou você se dedica a trabalhar pra ter um bom lucro ou então se você for fazer o artesanato só quando você disser agora terminei de fazer minhas coisas, terminei de arrumar a casa, vou me sentar e vou trabalhar você não vai ter um bom êxito (M. L. N. V. 40 anos, artesã).

Pra o artesanato você tem que ter força de vontade e coragem, [...] eu vejo assim, se eu preciso de uma renda, se eu não consigo ter uma renda de salário mínimo eu vou ter de meio. O importante é que eu não esteja de mão parada esperando só o que vier (M. L. N. V. 40 anos, artesã).

Com certeza. Se você não persistir, se acomodar você não vai pra frente, você tem que ter força de vontade e insistir no que você quer. Por exemplo, eu estou participando do projeto ai só porque você diz que está participando do projeto você esperar progresso. Você tá participando do projeto, mas você tem que fazer o que o projeto tá pedindo, união, interesse, persistência (M. L. N. V. 40 anos, artesã).

\section{Porém, nas entrelinhas do discurso lemos o contrário:}

Mulher eu acho que sim porque antigamente, que as meninas me dizem, assim tinha comprador, assim, mas era vago, e eu não trabalhava muito, mas agora eu sei aonde vende se eu quiser trabalhar e levar diretamente para quem compra, eu trabalho, mas é porque agora no momento eu não quero (J. O. S. 29 anos, artesã).

Às vezes sim, quando tem uma encomenda, mas eu num sou muito de tá trabalhando direto não, mas quando tem uma encomendinha assim uma aqui e uma acolá a gente trabalha sim (J. O. S. 29 anos, artesã).

Não é porque agora no momento eu to trabalhando com as camisas de garrafa, porque eu não tenho muito tempo, aí, eu estou me dedicando mais as camisas, tá entendendo (J. O. S. 29 anos, artesã).

No tocante ao quesito inovação e criatividade, duas delas são enfáticas ao afirmar a importância de inovar na criação de novas peças.

Eu acho que sim, aprender e buscar desenvolver mais algumas coisas que você não sabe ainda, apesar da pessoa saber trançar, mas tem umas coisas que a gente não sabe, tipo eu, tinha umas coisas que eu não sabia, ela (D. Luisa) via aqui e eu dizia, eu vou aprender e ai aprendi. E se Deus quiser ainda pretendo aprender mais outras coisas que eu ainda não sei (J. O. S. 29 anos, artesã).

\footnotetext{
7 Projeto "Mulheres da Palha: empreendedorismo social de artesãs da palha da carnaúba em Juazeiro do Norte, Ceará"
} 
(Continuação)

Com certeza, o problema maior do artesanato, no caso das artesãs da Rua do Horto se reclamar muito, é justamente isso ta faltando inovação, porque você sabe que você compra uma roupa hoje, mas quando for no final do ano, você for comprar outra e naquela loja só tiver igual ao modelo que você comprou em junho, você já vai procurar outro canto que tenha modelos mais novos, mais bonitos, então o artesanato, ele tá faltado isso elas se reunirem e tentar inovar peças, mesmo que seja aquelas mesmas peças mas que tenha algo de diferente do que o que você fez a um ano atrás, a seis meses atrás. Que é isso que tá faltando porque você faz uma bolsa, no caso, tem bolsas ai que há 25 anos ou mais mesmo se fazia aquele modelo, tinha muita procura, mas hoje se você fizer não tem essas procura, [...] os clientes pra usar uma coisa eles sempre tão procurando uma coisa nova, modelo novo, uma inovação, então as nossas é o que tá acontecendo, quando Jeanine veio propor esse projeto foi o que eu disse pra ela, que a gente precisava de um projeto, mas agente precisava de um projeto que inovasse, porque o que a gente já fazia todo mundo tava vendo, agora o que tava precisando na verdade era inovação, eu até disse a ela que não sabia o que era um projeto de design, mas o SEBRAE levou a gente para um congresso em Fortaleza e a palavra que mais se falava era design. $E$ eu não sabia o que era que significava design, aí eu fui e falei pra Jeanine que o que a gente tava precisando era de um projeto que ajudasse a gente a pensar, a ver como fazer uns novos modelos que o mercado procurasse que tivesse saída, porque o que a gente fazia todo mundo já tava enjoado (M. L. N. V. 40 anos, artesã).

\section{Considerações finais}

A proposta dessa pesquisa consistiu em estudar o empreendedorismo com foco em mulheres que trabalham com artesanato na cidade de Juazeiro do Norte, considerando o fato de que os estudos sobre o tema estão em ascensão, visto que o empreendedor desempenha um papel fundamental no desenvolvimento de uma região.

A formação da cidade de Juazeiro se deve, sobretudo, a atuação do 'Padim Ciço', que, baseando-se nas premissas do catolicismo popular, projetou a cidade à prosperidade tendo como alicerces de sustentação a díade fé e trabalho. Com seus ensinamentos estruturou um exército de fiéis e trabalhadores que, até os dias de hoje, compõe a cidade oficina.

Entre suas ações empreendedoras incentivou o cuidado com a terra e o aprendizado de arte. Baseado nisso, criou no povo sertanejo de Juazeiro a cultura do artesanato. Meio de sobrevivência adotado por boa parte da população local, advinda de todos os lugares, movidos principalmente pelo desejo de morar na terra santa do Padre Cícero e da Mãe das Dores. 
A partir disso, buscamos perceber se as características empreendedoras tão aceitas pela ciência favoreciam ou não a manutenção das atividades de um grupo de artesãs da cidade de Juazeiro do Norte - $\mathrm{CE}$, cidade esta que teve sua origem e desenvolvimento pautado nos ensinamentos do Padre Cícero, sendo pregado que em cada casa deveria haver uma oficina e um oratório.

Com base na análise feita a partir do confronto das falas dos atores participantes da pesquisa com o discurso dos teóricos, e da leitura da pesquisadora acerca do comportamento das artesãs, acredito que o pressuposto inicialmente defendido - as características empreendedoras reconhecidas pela ciência são encontradas nas artesãs de Juazeiro do Norte/CE bem como, que estas características desempenham um papel importante no favorecimento da manutenção de seus estabelecimentos - não pode ser confirmado.

As observações e depoimentos colhidos no campo nos fazem inferir que a atividade artesanal realizada pelas artesãs decorre principalmente da necessidade de compor a renda familiar para sobreviver, visto que, as mesmas são frutos de um meio repleto de obstáculos que não deram margem para a busca de condições melhores de vida.

Nos ditos, e nos não ditos (silêncios e gestos), as artesãs demonstraram que apesar de trabalharem com artesanato, não se sentem realizadas com o que fazem. Nem a longa trajetória de trabalho com artesanato, nem a importância deste para sobrevivência das artesãs parecem suficientes para promover satisfação com o trabalho. $O$ fazem pela necessidade de sobrevivência, pois, segundo elas, não tiveram acesso a outras oportunidades.

Dos momentos de convívio, durante a pesquisa, cabe pontuar que, as mulheres entrevistadas possuem compreensão limitada das oportunidades que rondam a todo instante suas realidades. Diferentemente do perfil empreendedor traçado pelos autores citados neste texto. Outro elemento, que reforça considerar que o pressuposto não pode ser confirmado, foi perceber a dependência das artesãs em outros atores sociais. Elas entendem a ação de terceiros como determinante para o sucesso do empreendimento. Tal atitude passiva contribui para distorcer a percepção destas mulheres, que não acreditam que o progresso da atividade desempenhada depende, sobretudo, delas.

Compreendemos que a temática exige estudos posteriores mais aprofundados, sobretudo, a respeito do que contribui para a manutenção desses "empreendimentos da sobrevivência" e qual e/ou se é possível pensar numa perspectiva de crescimento destes. No 
entanto, consideramos que a pesquisa contribui para o campo, naquilo que residiu o seu maior desafio, compartilhar um pouco da experiência destas mulheres artesãs, proporcionando a outros o acesso à história de vida de pessoas que também fazem parte da história da cidade em que se inserem, aguçando olhos e ouvidos para outras realidades, promovendo uma via que permita que a história local seja apropriada e reinventada, contada e recontada, por outros cidadãos que construirão conhecimentos a partir de trocas e convivências.

\section{Referências}

ANDREOLI, T. P.; BORGES, W. A. Empreendedorismo feminino: uma análise do perfil empreendedor e das dificuldades enfrentadas por mulheres detentoras de um pequeno negócio. In: XI Encontro Parana internetaense dos Estudantes de Administração (EPEAD). Maringá, 2007.

ARAÚJO, M. L. de. A Cidade do Padre Cícero: trabalho e fé. Tese (Doutorado) - Universidade Federal do Rio de Janeiro, Rio de Janeiro, 2005.

BARROSO, H. C.; FROTA, M. H. de P. A trama do trabalho artesanal para mulheres cearenses: desenvolvendo códigos de gênero. In: Fazendo Gênero 9. Santa Catarina, 2010. Disponível em: $<$ http://www.fazendogenero.ufsc.br/9/resources/anais/1278297991_ARQUIVO_fazendogen ero.pdf>. Acesso em: 7 abr. 2017.

BAQUIT, S. H. C. A Análise da Experiência de Negócios da Cooperativa Pirambú Digital em Fortaleza/CE. Dissertação (Mestrado) - Universidade Estadual do Ceará, Fortaleza, 2008.

CAMPOS, E. M. Práxis Empreendedora e a Sustentabilidade dos Agronegócios Frutícolas. Dissertação (Mestrado) - Universidade Estadual do Ceará, Fortaleza, 2008.

CARVALHO, G. Madeira matriz. Cultura e memória. São Paulo: Anna Blume, 1999.

COLLINS, O. F.; MOORE, D. G.; UNWALLA, D. B. The Enterprising Man. MSU Business Studies, Bureau of Business and Economic Research, Graduate School of Business Administration. Michigan State University, East Lansing, Michigan, 1964.

COLLINS, O. F.; MOORE, D. G. The Organization Makers: A Behavioral Study of Independent Entrepreneurs. New York: Appleton-Century-Crofts (Meredith Corp.), 1970.

DELLA CAVA, R. Milagre em Joaseiro. Rio de Janeiro: Paz e Terra, 1985. 
CASTRO, M. de S.; M., OLIVEIRA, A. A.; PEREIRA, W. E. N. Panorama e dinâmica recente da economia da Região Metropolitana do Cariri-RMC. Revista de Economia Regional, Urbana e do Trabalho, v. 2, n. 1, p. 47-58, 2016. Disponível em: <https://ojs.ccsa.ufrn.br/index.php? journal=rerut\&page=article\&op=view\&path\%5B\%5D=599>. Acesso em: 7 abr. 2017.

DORNELAS, J. C. A. Empreendedorismo: transformando ideias em negócios. 3. ed. Rio de Janeiro: Elsevier, 2008.

FÉLIX, W. J. S. Valei-me meu Padim: Um Estudo Sobre a Cultura, os 'Negócios da Fé' e o Desenvolvimento Territorial de Juazeiro do Norte. Dissertação (Mestrado) - Universidade Estadual do Ceará, Fortaleza, 2008.

FERREIRA, E. F. X. Mujeres, Memória e Identidad Política. In: Historia, Antropologia e Fuentes Orales. Revista de Sociologia, n. 21, p. 53-66, 1999.

FIGUEIREDO, M. D. et al. Empreendedorismo feminino no artesanato: uma análise crítica do caso das rendeiras dos Morros da Mariana. Revista Eletrônica de Ciência Administrativa, v. 14, n. 2, p. 110-123, 2015. Disponível em:

<http://www.spell.org.br/documentos/ver/42151/empreendedorismo-feminino-noartesanato--uma-analise-critica-do-caso-das-rendeiras-dos-morros-da-mariana--piaui>. Acesso em: 7 mar. 2017.

FILION, L. J. Empreendedorismo: empreendedores e proprietários-gerentes de pequenos negócios. Revista de Administração da Universidade de São Paulo, São Paulo v. 34, n. 2, p. 5-28, abr./jun. 1999. Disponível em:

<http://www.spell.org.br/documentos/ver/18122/empreendedorismo--empreendedores-eproprietarios-gerentes-de-pequenos-negocios>. Acesso em: 7 abr. 2017.

From Entrepreneurship to Entreprenology. Journal of Best Papers, Ed. 0. Kunkel, Scott W., 1997.

GEERTZ, C. A interpretação das culturas. Rio de Janeiro: LT\&C, 1989.

GEM. Global Entrepreneurship Monitor. 2015. Disponível em:

<http://www.bibliotecas.sebrae.com.br/chronus/ARQUIVOS_CHRONUS/bds/bds.nsf/482617 1de33895ae2aa12cafe998c0a5/\$File/7347.pdf>. Acesso em: 10 maio 2017.

GRANGEIRO, R. R.; BASTOS, A. V. B. Organização do trabalho artesanal: examinando aspectos de inovação e visibilidade do artesanato no Cariri cearense. Revista de Psicologia, v. 7, n. 2, p. 33-48, 2016. Disponível em:

<http://www.periodicos.ufc.br/psicologiaufc/article/viewFile/6274/4492>. Acesso em:

7 abr. 2017. 
GREATTI, L. SENHORINI, V. M. Empreendedorismo: uma visão comportamentalista. In: Encontro de Estudos sobre Empreendendorismo e Gestão de Pequenas Empresas (Egepe), 1., 2000, Maringá. Anais... Maringá: Egepe, 2000. 1 CD-ROM.

HISRICH, R D.; PETERS, M. P. Empreendedorismo. 5. ed. Bookman, 2004.

INSTITUTO BRASILEIRO DE GEOGRAFIA ESTATÍ́STICA. IBGE. Censo 2010. Disponível em: <http://www.censo2010.ibge.gov.br/primeiros_dados_divulgados/index.php?uf=23>. Acesso em: 7 abr. 2017.

INÁCIO JÚNIOR, E. Empreendedorismo e Liderança Criativa: um estudo com os Proprietáriosgerentes de empresas incubadas no Estado do Paraná. 2002. Dissertação (Mestrado) Universidade Federal de Maringá, Maringá, 2002.

LONGEN, M. T. Um modelo comportamental para o estudo do perfil do empreendedor. Dissertação (Mestrado - Faculdade de Engenharia de Produção) - Universidade Federal de Santa Catarina, Florianópolis, 1997.

MARQUESAN, F. F. S.; FIGUEIREDO, M. D. De Artesão a Empreendedor: A Ressignificação do Trabalho Artesanal Como Estratégia para a Reprodução de Relações Desiguais de Poder. Revista de Administração Mackenzie, v. 15, n. 6, 2014. Disponível em: <http://editorarevistas.mackenzie.br/index.php/RAM/article/view/7096/5238>. Acesso em: 10 mar. 2017.

NAIR, K. R. G.; PANDEY, A. Characteristics of entrepreneurs: an empirical analysis. Journal of Entrepreneurship, v. 15, n. 1, p. 47-61, 2006. Disponível em:

$<$ https://www.researchgate.net/publication/247767049_Characteristics_of_EntrepreneursAn _Empirical_Analysis>. Acesso em: 10 mar. 2017.

OLIVEIRA, J. R. C.; SILVA, W. A. C.; ARAUJO, E. A T. Características comportamentais empreendedoras em proprietários de MPEs longevas do Vale do Mucuri e Jequitinhonha/MG. Revista de Administração Mackenzie, v. 15, n. 5, p. 102-139, 2014. Disponível em: <http://www.scielo.br/scielo.php?script=sci_arttext\&pid=S167869712014000500005\&lng=en\&nrm=iso>. Acesso em: 10 fev. 2017.

PAULINO, A. D; ROSSI, S. M. M. Um estudo de caso sobre perfil empreendedor: características e traços de personalidade empreendedora. In: Anais EGEPE, Encontro de Estudos sobre empreendedorismo e gestão de pequenas empresas, Brasília/DF, 2003. Disponível em: <http://www.dad.uem.br/adm/graduacao/download/2762-07.pdf>. Acesso em: 10 fev. 2017. 
ROSSONI, L.; TEIXEIRA, R. M. Integrando empreendedorismo, rede de relações, recursos e legitimidade: o caso da aliança empreendedora. In: Anais ENANPAD, XXX Encontro Anual da Associação Nacional dos Programas de Pós-Graduação em Administração, Salvador, 2006. Disponível em:

<https://ri.ufs.br/bitstream/123456789/783/1/IntegrandoEmpreendedorismoRecursos.pdf>. Acesso em: 9 abr. 2017.

SCHUMPETER, J. A. Teoria do desenvolvimento econômico: uma investigação sobre lucra, capital, crédito, juro e o ciclo econômico. São Paulo: Abril Cultural, 1982.

SHANE, S.; VENKATARAMAN, S. The promise of entrepreneurship as a field of research. Academy of Management Review, n. 25, v. 1, p. 217-226, 2000. Disponível em:

$<$ https://entrepreneurscommunicate.pbworks.com/f/Shane\%2520\%252B\%2520Venkat\%252 0-\%2520Ent\%2520as\%2520field.pdf>. Acesso em: 9 jan. 2017.

STINGHEN, M.G. Padre Cícero: a canonização popular. Dissertação (Mestrado) - Universidade Estadual de Campinas, Campinas, 2000.

VERGARA, S.; SILVA, H. Organizações artesanais: um sistema esquecido na teoria das organizações. Revista Portuguesa e Brasileira de Gestão, v. 6, n. 3, p. 32-38, 2007. Disponível em: <http://www.scielo.mec.pt/scielo.php?script=sci_arttext\&pid=S1645$44642007000300004 \&$ Ing=pt\&nrm=iso>. Acesso em: 9 abr. 2017.

WEBER, M. A ética protestante e o espírito do capitalismo. São Paulo: Cengage Learning, 2005.

ZALEZNIK, A.; KETS DE VRIES, M. F. R. Power and the corporate mind. Boston: Houghton Mifflin, 1975. 